\title{
Weather Resistance of Porcelain Enamels Exposed for Seven Years
}

\author{
By William N. Harrison and Dwight G. Moore
}

\begin{abstract}
A study of the weather resistance of porcelain-enameled architectural panels was begun at the National Bureau of Standards in 1939. The study involves 864 1-foot-square panels and a like number of 4- by 6-inch laboratory specimens. A previous report (1942) gave the results after 1 year of exposure. The present paper describes the condition of the panels after 7 years of weathering at Washington, D. C., St. Louis, Mo., Lakeland, Fla., and Atlantic City, N. J.

The results of the 7 -year inspection showed a good correlation between the acid resistance of enamels and their resistance to weathering. Where initial coverage was complete and no mechanical damage had occurred, protection of the metal by the enamel for all specimens was unimpaired after 7 years.
\end{abstract}

Fading of colored enamels occurred only on those panels with very poor acid resistance.

\section{Introduction}

During the past 2 decades, the increased use of porcelain enamel as an architectural material, including its recent application in the low-cost housing field $[1,2],{ }^{1}$ has accentuated the need for adequate data on the weather resistance of various types of enamel and also for laboratory tests to indicate weather resistance.

An investigation designed to obtain such data was begun by the Enameled Metals Section of the National Bureau of Standards in 1939 and was planned with the assistance of an advisory committee from the industry. Through the cooperation of 16 manufacturers, 864 1-ft-sq. panels and an equal number of 4 - by 6 -in. laboratory specimens were prepared. Most of the enamels furnished were regular commercial products, but they were not, in all cases, enamels that had been proved suitable for architectural purposes. On the contrary some were not expected to have good resistance to weathering. The exposure sites selected were Washington, D. C.; St. Louis, Mo.; Lakeland, Fla.; and Atlantic City, N. J.

The present paper, which describes the test panels after $7 \mathrm{yr}$ of exposure, is the second progress report of this investigation. The first report, describing the results obtained for 1 year of exposure, was published in 1942 [3]. The lapse of 6 years between the first and second progress reports was due to the impracticability of carrying out a regular inspection program during the war years.

\section{Conditions Prevailing at Locations of Exposure}

Table 1 lists the exposure locations, and table 2 gives pertinent data on weather conditions during the 7-yr period of exposure at each site. At all four locations the racks face south, the panels being exposed at $45^{\circ}$ from the horizontal.

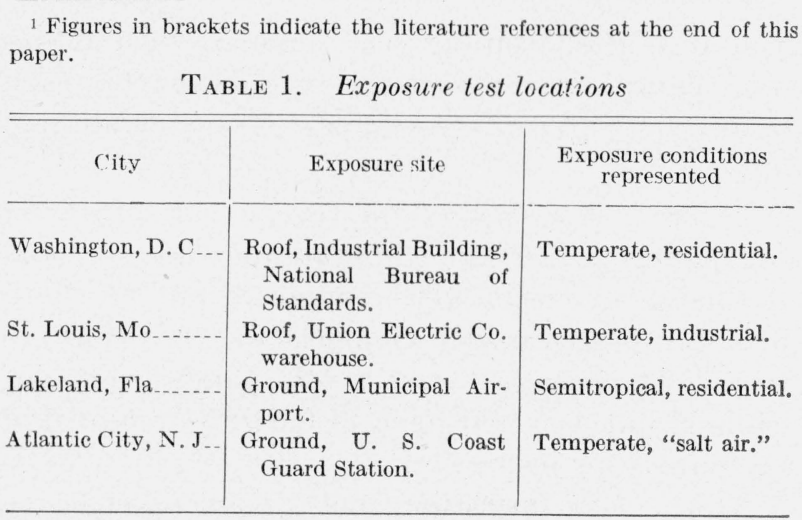


TABLE 2. General weather data for the first 7 years of exposure (from U. S. Weather Bureau records)

\begin{tabular}{|c|c|c|c|c|}
\hline City & Exposure period & $\begin{array}{c}\text { Annual } \\
\text { rain- } \\
\text { fall : }\end{array}$ & $\begin{array}{c}\text { Annual } \\
\text { sun- } \\
\text { shine } 1\end{array}$ & $\begin{array}{l}\text { A ver- } \\
\text { age } \\
\text { temper- } \\
\text { ature } 1\end{array}$ \\
\hline Washington, D. C & $\begin{array}{l}\text { Dec. } 1939 \text { through Nov. } \\
\quad 1946 .\end{array}$ & $\begin{array}{l}\text { in. } \\
39.8\end{array}$ & $\begin{array}{l}h r \\
2,597\end{array}$ & ${ }^{\circ} \mathrm{F}$ \\
\hline St. Louis, Mo & $\begin{array}{l}\text { April } 1940 \text { through May } \\
\text { 1947. }\end{array}$ & 39.7 & 2,770 & 57.3 \\
\hline Lakeland, Fla..... & $\begin{array}{l}\text { July } 1940 \text { through March } \\
1947 .\end{array}$ & 47.7 & ${ }^{2} 2,945$ & 72.3 \\
\hline Atlantic City, N. J & $\begin{array}{l}\text { Aug. } 1940 \text { through April } \\
\text { 1947. }\end{array}$ & 40.0 & 2,751 & 53.7 \\
\hline
\end{tabular}

${ }^{1}$ A verage computed from data for actual period of exposure.

${ }^{2}$ Taken from Tampa, Fla., records. Total sunshine for Lakeland not available.

\section{General Description of Panels}

The 14 types of enamel included in the study are indicated in table 3 . For a more complete description of the specimens and their fabrication, reference is made to the first report [3].

The supporting racks were constructed of angle the general condition of both panels and racks. The following remarks summarize their condition at each location.

\section{Panels at Washington, D. C.}

All panels and racks were in comparatively good condition. Periodic painting of the steel racks had been possible during the war years, and no serious corrosion had taken place. The panels were substantially free from dirt and grime and the natural washing by rain was apparently all that was required at this location to keep surface deposits from accumulating.

On one panel $(\mathrm{V}-71)$ the surface had been accidentally fractured in April of 1941, resulting in a local exposure of the metal. It was estimated that during the interventing $6 \mathrm{yr}$, corrosion had progressed into the metal to a depth of 0.003 in., but there was apparently no appreciable penetration of the corrosion under the adjacent enamel. The size of the fracture had not increased from its original $1 / 2$-in. diameter.

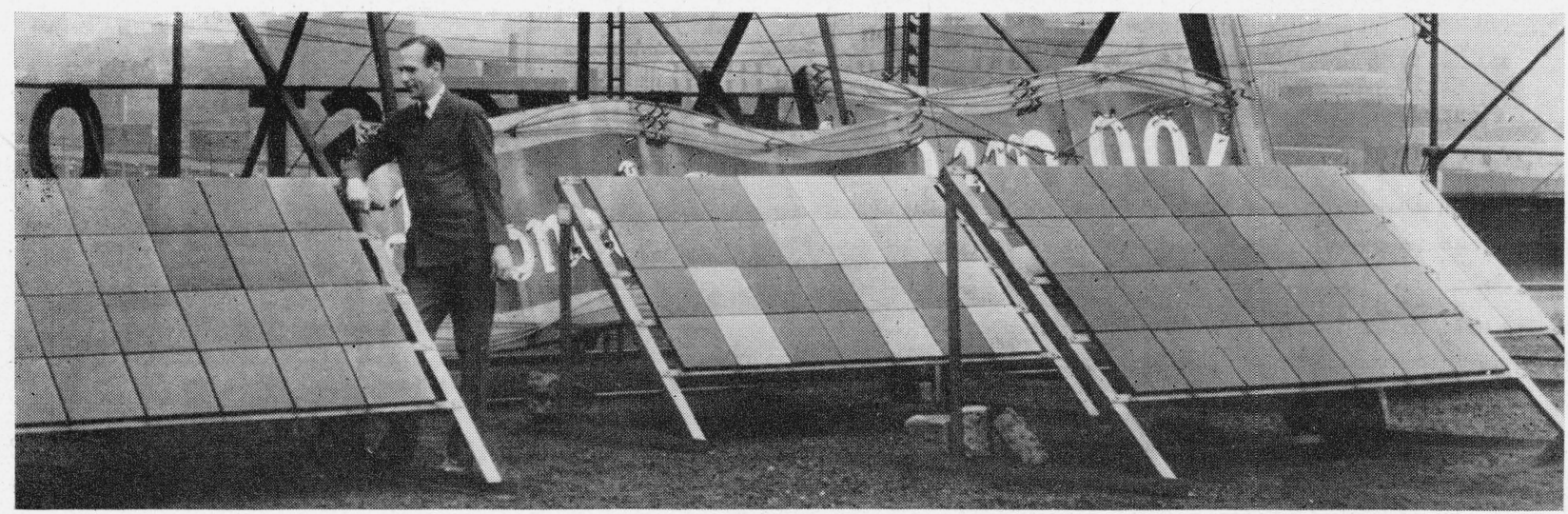

Figure 1. Partial view of exposure-test installation on roof of Union Electric Co. warehouse in St. Louis, Mo., near the railway terminal.

Photograph taken in 1941 before heavy deposit of combustion products had formed on panel surfaces (see page 48).

iron and, after priming, were painted with aluminum paint. Seven racks were required for each location. Figure 1 shows a part of the installation at St. Louis.

Figure 2 is a view of the reverse side of one of the panels. The two clips at one side $(C)$ and the flange extension at the opposite side $(F)$ both fitted into galvanized channels on the exposure rack. The spaces between the panels were not caulked but were left open to facilitate removal of the panels for inspection.

At the 7-yr inspection, notes were taken as to

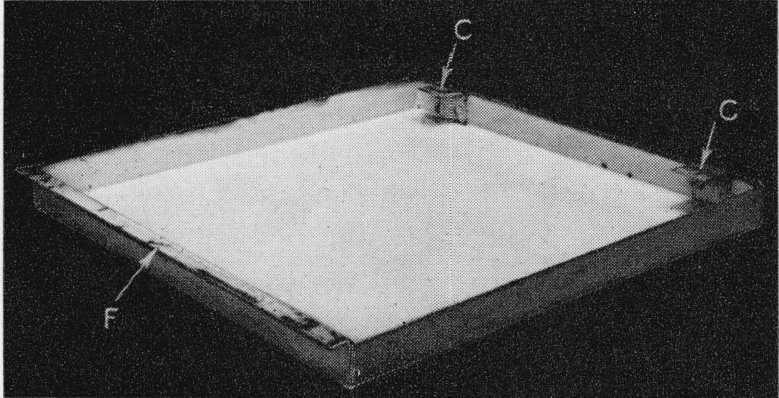

Figure 2. View of the reverse side of a panel showing attachment of clips $(C)$ and lower flange extension $(F)$ used for fastening panels to racks. 
TABLE 3. Percentage of initial specular gloss retained by 14 enamels for 7 years at four exposure locations and results of acidresistance tests on same compositions

Specimen identification 1

\begin{tabular}{|c|c|c|c|c|c|c|c|}
\hline \multirow{2}{*}{$\begin{array}{l}\text { Fabri- } \\
\text { cator }\end{array}$} & \multirow{2}{*}{$\begin{array}{c}\text { A verage } \\
45^{\circ} \text { initial } \\
\text { specular } \\
\text { gloss }\end{array}$} & \multicolumn{5}{|c|}{ Average percentage of initial specular gloss retained at -3} & \multirow{2}{*}{$\begin{array}{c}\text { Acid re- } \\
\text { sistance } \\
\text { PEI } \\
\text { test }^{4}\end{array}$} \\
\hline & & $\begin{array}{c}\text { Washing- } \\
\text { ton }\end{array}$ & St. Louis ${ }^{2}$ & $\underset{\text { City }}{\text { Atlantic }}$ & Lakeland & $\begin{array}{l}\text { A verage } \\
\text { for three } \\
\text { locations }\end{array}$ & \\
\hline
\end{tabular}

WHITE, GLOSSY, ACID-RESISTANT ENAMEL

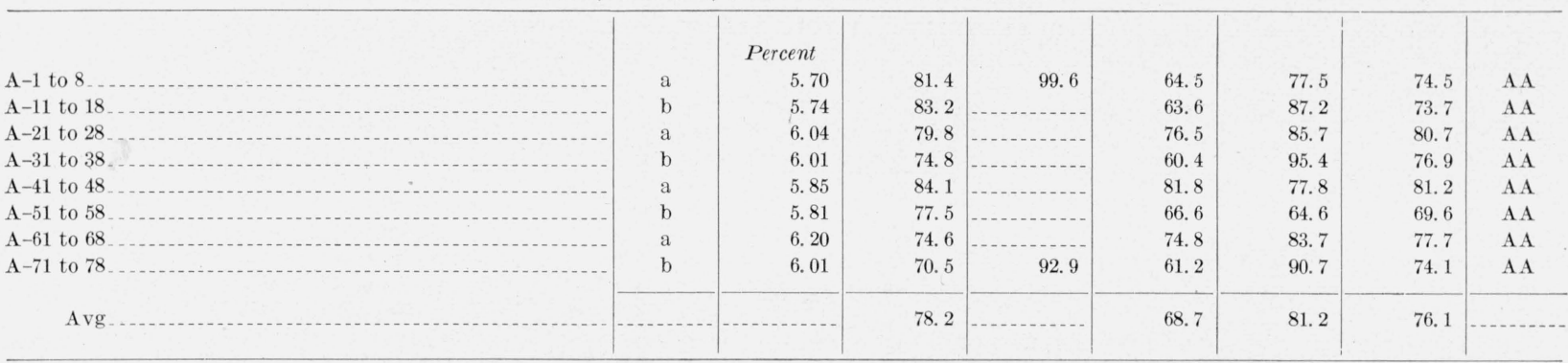

WHITE, GLOSSY, NONACID-RESISTANT ENAMEL

\begin{tabular}{|c|c|c|c|c|c|c|c|c|}
\hline $\mathrm{B}-1$ to 8 & $\mathrm{~b}$ & 5. 26 & 28.9 & & 44.4 & 37. 7 & 37.0 & $\mathrm{C}$ \\
\hline B-21 to 28 & $\mathrm{~b}$ & 5.41 & 34.8 & ..... & 36.4 & 26.4 & 32.5 & $\mathrm{C}$ \\
\hline B-41 to 48 & $\mathrm{~b}$ & 5. 16 & 26.5 & 48.2 & 37. 7 & 26.4 & 30.2 & $\mathrm{D}$ \\
\hline B-61 to 68 & $\mathrm{~b}$ & 5.32 & 34.8 & - & 43.4 & 37.7 & 38.6 & $\mathrm{C}$ \\
\hline Avg. & & & 31.2 & & 40.5 & 32.0 & 34.6 & \\
\hline
\end{tabular}

WHITE, SEMIMAT, ACID-RESISTANT ENAMEL

\begin{tabular}{|c|c|c|c|c|c|c|c|c|}
\hline $\mathrm{C}-11$ to $18 \ldots$. & $\mathrm{c}$ & 4.06 & 51.8 & $>100.0$ & 50.2 & 45.0 & 49.0 & $\mathrm{C}$ \\
\hline $\mathrm{C}-31$ to 38 & $\mathrm{c}$ & 5.24 & 61.5 & & 42.0 & 64.8 & 56.1 & A \\
\hline $\mathrm{C}-51$ to 58 & $\mathrm{c}$ & 5. 16 & 76.8 & $\ldots$ & 58.1 & 80.5 & 71.8 & A \\
\hline $\mathrm{C}-71$ to 78 & $\mathrm{c}$ & 5. 32 & 73.1 & - n & 60.2 & 70.3 & 67.9 & A \\
\hline Avg... & $\ldots$ & & 65.8 & & 52.6 & 65.1 & 61.2 & \\
\hline
\end{tabular}

WHITE, SEMIMAT, NONACID-RESISTANT ENAMEL

\begin{tabular}{|c|c|c|c|c|c|c|c|c|}
\hline D-1 to $8 \ldots \ldots$ & c & $\left({ }^{5}\right)$ & & & & & & $\mathrm{D}$ \\
\hline D-21 to 28 & $\mathrm{c}$ & 5. 69 & 43.2 & . & 46.0 & 41.8 & 43. 7 & $\mathrm{D}$ \\
\hline D-41 to 48 & $\mathrm{c}$ & 5. 51 & 38.0 & $\ldots$ & 31.9 & 36.6 & 35.5 & $\mathrm{D}$ \\
\hline D-61 to $68 \ldots$ & $\mathrm{c}$ & & & & & & & $\mathrm{U}$ \\
\hline Avg & & & 40.6 & & 38.9 & 39.2 & 39.6 & \\
\hline
\end{tabular}

BUFF, GLOSSY, ACID-RESISTANT ENAMEL

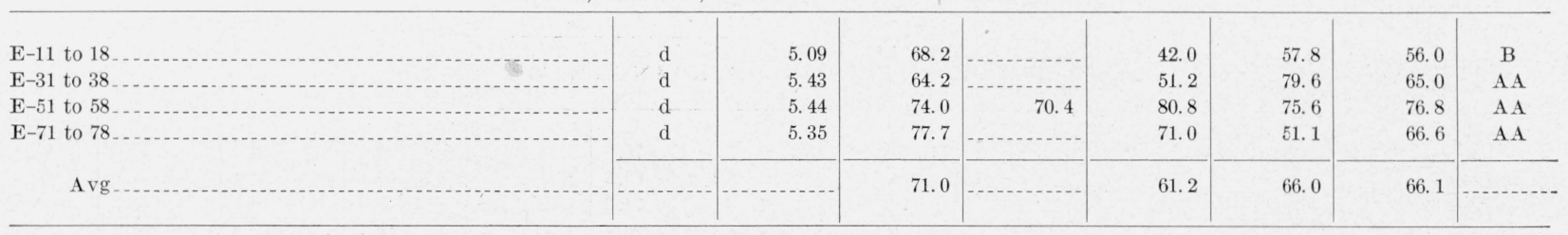

BUFF, GLOSSY, NONACID-RESISTANT ENAMEL

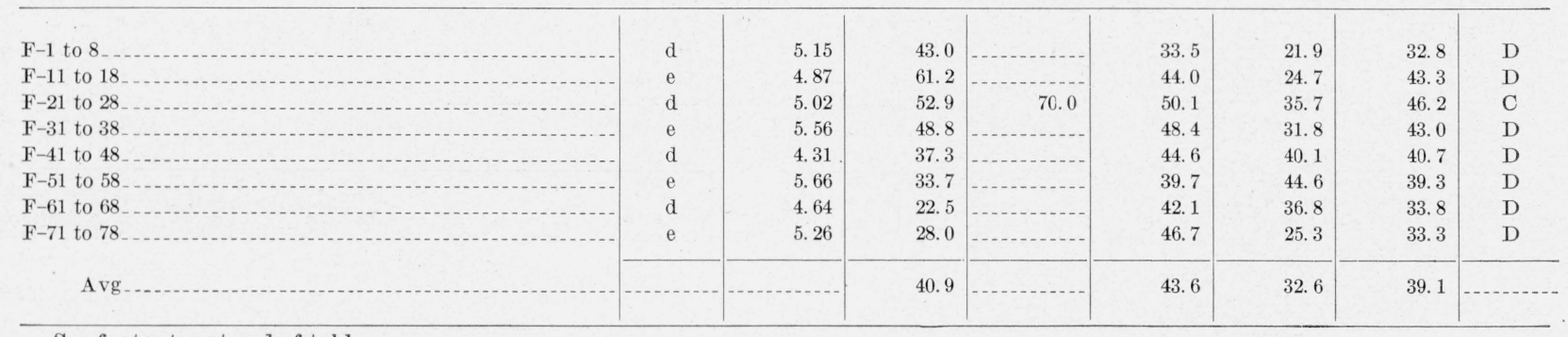

See footnotes at end of table. 
TABLE 3. Percentage of initial specular gloss retained by 14 enamels for 7 years at four exposure locations and results of acidresistance tests on same compositions-Continued

\begin{tabular}{|c|c|c|c|c|c|c|c|c|}
\hline \multirow[b]{2}{*}{ Specimen identification ${ }^{1}$} & \multirow[b]{2}{*}{$\begin{array}{l}\text { Fabri- } \\
\text { cator }\end{array}$} & \multirow{2}{*}{$\begin{array}{l}\text { A verage } \\
45^{\circ} \text { initial } \\
\text { specular } \\
\text { gloss }\end{array}$} & \multicolumn{5}{|c|}{ A verage percentage of initial specular gloss retained at -3} & \multirow{2}{*}{$\begin{array}{l}\text { Acid re- } \\
\text { sistance } \\
\text { PEI } \\
\text { test } 4\end{array}$} \\
\hline & & & $\begin{array}{l}\text { Washing- } \\
\text { ton }\end{array}$ & St. Louis ${ }^{2}$ & $\underset{\text { City }}{\text { Atlantic }}$ & Lakeland & $\begin{array}{l}\text { A verage } \\
\text { for three } \\
\text { locations }\end{array}$ & \\
\hline
\end{tabular}

BUFF, SEMIMAT, ACID-RESISTANT ENAMEL

\begin{tabular}{|c|c|c|c|c|c|c|c|c|}
\hline $\mathrm{H}-1$ to $8 \ldots . .$. & e & $\begin{array}{r}\text { Percent } \\
3.96\end{array}$ & 60.7 & . & 62.5 & 55.2 & 59.5 & A \\
\hline $\mathrm{H}-11$ to 18 & f & 4. 81 & 57.6 & ......... & 70.6 & 57.0 & 61.7 & A \\
\hline $\mathrm{H}-21$ to 28 & e & 5.65 & 70.7 & & ..... & 63.1 & 66.9 & A \\
\hline H-31 to 38 & $\mathrm{f}$ & 5.45 & 71.2 & & 40.1 & 70.5 & 60.6 & A \\
\hline $\mathrm{H}-41$ to 48 & e & 4. 74 & 75.7 & $>100.0$ & 80.6 & 81.9 & 79.4 & $\mathrm{AA}$ \\
\hline $\mathrm{H}-51$ to 58 & f & 4.85 & 72.5 & & 69.6 & 74.5 & 72. 2 & AA \\
\hline H-61 to 68 & $\mathrm{e}$ & 5.51 & 74.4 & $>100.0$ & 56.6 & 88.0 & 73. 0 & AA \\
\hline $\mathrm{H}-71$ to 78 & f & 5.54 & 76.4 & & 60.2 & 81.4 & 72.7 & AA \\
\hline Avg ............... & & & 69.9 & & 62.9 & 71.5 & 68.3 & \\
\hline
\end{tabular}

BUFF, SEMIMAT, NONACID-RESISTANT ENAMEL

\begin{tabular}{|c|c|c|c|c|c|c|c|c|}
\hline $\mathrm{K}-1$ to $8 \ldots \ldots$ & f & $\left({ }^{3}\right)$ & & & & & & $\mathrm{D}$ \\
\hline $\mathrm{K}-11$ to 18 & $\mathrm{~g}$ & $\left({ }^{5}\right)$ & - n. & - . & . & - n & 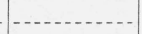 & $\mathrm{D}$ \\
\hline $\mathrm{K}-21$ to 28 & f & 5.41 & 49.0 & 75.3 & 47.3 & 38.8 & 45.0 & $\mathrm{D}$ \\
\hline $\mathrm{K}-31$ to 38 & $\mathrm{~g}$ & 5.37 & 36.4 & (........ & 48.2 & 27. 6 & 37.4 & $\mathrm{D}$ \\
\hline K-41 to $48 \ldots$ & f & 5.20 & 63.5 & 73.8 & 49.5 & 46.7 & 53.2 & $\mathrm{D}$ \\
\hline K-51 to $58 \ldots \ldots \ldots$ & $\mathrm{g}$ & 5.35 & 36.5 & -... & 42.4 & 29.4 & 36.1 & $\mathrm{D}$ \\
\hline K-61 to $68 \ldots \ldots$ & $\mathrm{f}$ & $\left({ }^{5}\right)$ & & & & & & $\mathrm{D}$ \\
\hline K-71 to 78 & $\mathrm{~g}$ & $\left({ }^{5}\right)$ & (n............. & - n & -... & 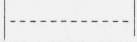 & & $\mathrm{D}$ \\
\hline Avg... & & & 46.4 & $\ldots$ & 46.9 & 35.6 & 42.9 & \\
\hline
\end{tabular}

RED, GLOSSY, ACID-RESISTANT ENAMEL

\begin{tabular}{|c|c|c|c|c|c|c|c|c|}
\hline $\mathrm{L}-1$ to $8 \ldots \ldots . . . . . . .$. & $\mathrm{g}$ & 5.58 & 76.4 & 97.1 & 77.7 & 99.2 & 84.4 & AA \\
\hline L-11 to 18 & $\mathrm{~h}$ & 5. 61 & 74.7 & (n) & 88.6 & 96.5 & 86.6 & AA \\
\hline $\mathrm{L}-21$ to 28 & $\mathrm{~g}$ & 5.42 & 78.1 & - & 57.4 & 86.7 & 74.1 & $\mathrm{~B}$ \\
\hline L-31 to 38 & $\mathrm{~h}$ & 5. 64 & 79.7 & & 49.6 & 92.8 & 74.0 & A \\
\hline $\mathrm{L}-41$ to 48 & $\mathrm{~g}$ & 5.58 & 75.7 & - n & 78. 7 & 94.1 & 82.8 & AA \\
\hline L-51 to 58 & $\mathrm{~h}$ & 5. 23 & 67.6 & $-\ldots$ & 79. 7 & 86.6 & 78.0 & A \\
\hline $\mathrm{L}-61$ to 68 & $\mathrm{~g}$ & 5. 30 & 73.2 & - & 76.3 & 91.0 & 80.2 & A \\
\hline L-71 to 78 & $\mathrm{~h}$ & 4.18 & 74.0 & - & 82.7 & 78.1 & 78.3 & AA \\
\hline Avg $\ldots$ & & ...... & 74.9 & $\ldots$ & 73.8 & 90.6 & 79.8 & \\
\hline
\end{tabular}

RED, GLOSSY, NONACID-RESISTANT ENAMEL

\begin{tabular}{|c|c|c|c|c|c|c|c|c|}
\hline $\mathrm{N}-1$ to $8 \ldots \ldots . . .$. & $\mathrm{h}$ & 5.17 & 70.0 & & 62.3 & 40.2 & 57.5 & $\mathrm{C}$ \\
\hline $\mathrm{N}-11$ to 18 & $\mathrm{k}$ & 5.05 & 60.9 & & 55.0 & 39.9 & 51.9 & $\mathrm{C}$ \\
\hline $\mathrm{N}-21$ to 28 & $\mathrm{~h}$ & 5. 12 & 74.3 & & 48.4 & 46.1 & 56.3 & $\mathrm{D}$ \\
\hline $\mathrm{N}-31$ to 38 & $\mathrm{k}$ & 4. 55 & 70.4 & $\ldots$ & 59.2 & 53.6 & 61.1 & $\mathrm{D}$ \\
\hline $\mathrm{N}-41$ to 48 & $\mathrm{~h}$ & 5. 17 & 65.0 & & 62.4 & 35.0 & 54.1 & $\mathrm{C}$ \\
\hline $\mathrm{N}-51$ to 58 & $\mathrm{k}$ & 4. 68 & 61.4 & & 52.8 & 52.8 & 55.7 & $\mathrm{C}$ \\
\hline $\mathrm{N}-61$ to 68 & $\mathrm{~h}$ & 4. 71 & 43.0 & $-\ldots$ & 57.4 & 32.9 & 44.4 & $\mathrm{D}$ \\
\hline $\mathrm{N}-71$ to $78 \ldots$ & $\mathrm{k}$ & 5.44 & 36.4 & 38.4 & 52.9 & 44.8 & 54.4 & D \\
\hline Avg... & & & 60.2 & & 56.3 & 43.2 & 54.4 & \\
\hline
\end{tabular}

See footnotes at end of table. 
TABLE 3. Percentage of initial specular gloss retained by 14 enamels for 7 years at four exposure locations and results of acidresistance tests on same compositions - Continued

Specimen identification 1

\begin{tabular}{|c|c|c|c|c|c|c|c|}
\hline \multirow{2}{*}{$\begin{array}{l}\text { Fabri- } \\
\text { cator }\end{array}$} & \multirow{2}{*}{$\begin{array}{l}\text { A verage } \\
45^{\circ} \text { initial } \\
\text { specular } \\
\text { gloss }\end{array}$} & \multicolumn{5}{|c|}{ A verage percentage of initial specular gloss retained at - 3} & \multirow{2}{*}{$\begin{array}{c}\text { Acid re- } \\
\text { sistance } \\
\text { PEI } \\
\text { test }{ }^{4}\end{array}$} \\
\hline & & $\begin{array}{c}\text { Washing- } \\
\text { ton }\end{array}$ & St. Lou is ${ }^{2}$ & $\underset{\text { City }}{\text { Atlantic }}$ & Lakeland & $\begin{array}{l}\text { A verage } \\
\text { for three } \\
\text { locations }\end{array}$ & \\
\hline
\end{tabular}

RED, SEMIMAT, ACID-RESISTANT ENAMEL

\begin{tabular}{|c|c|c|c|c|c|c|c|c|}
\hline $\mathrm{P}-1$ to 8 & $\mathrm{k}$ & $\begin{array}{r}\text { Percent } \\
5.54\end{array}$ & 70.3 & & 77.1 & 81.0 & 76.1 & AA \\
\hline P-11 to 18 & 1 & $(5)$ & (n) & 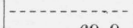 & (n- & (n- & 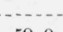 & AA \\
\hline P-21 to $28 \ldots \ldots$. & $\mathrm{k}$ & 1. 41 & 62.6 & 69.9 & 49.1 & 65.4 & 59.0 & $\mathrm{C}$ \\
\hline P-31 to 38 & 1 & 3.99 & 64.4 & - n & 58.7 & 42.9 & 55.3 & $\mathrm{C}$ \\
\hline P-41 to 48 & $\mathrm{k}$ & 4. 95 & 69.2 & -...... & 66.7 & 75.4 & 70.4 & A \\
\hline P-51 to $58 \ldots \ldots$ & 1 & 3.34 & 73.8 & - & 73.4 & 84.1 & 77.1 & A \\
\hline $\mathrm{P}-61$ to $68 \ldots$ & $\mathrm{k}$ & 4.97 & 76.2 & 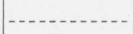 & 66.4 & 92.9 & 78.5 & AA \\
\hline P-71 to $78 \ldots$ & 1 & 5.54 & 81.0 & - no...... & 81.3 & 97.2 & 86.5 & AA \\
\hline Avg & & 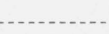 & 71.1 & & 67.5 & 77.0 & 71.1 & \\
\hline
\end{tabular}

RED, SEMIMAT, NONACID-RESISTANT ENAMEL

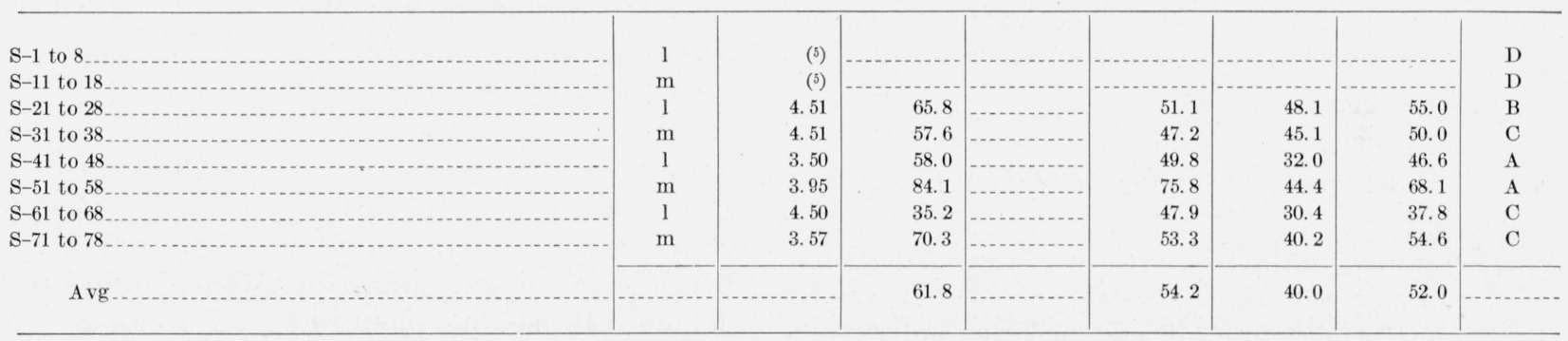

BLACK, GLOSSY, ACID-RESISTANT ENAMEL

\begin{tabular}{|c|c|c|c|c|c|c|c|c|}
\hline $\mathrm{T}-1$ to $8 \ldots$ & $\mathrm{m}$ & 7.30 & 56.1 & & 47. 8 & 56.3 & 53.4 & AA \\
\hline $\mathrm{T}-11$ to $18 \ldots \ldots$ & $\mathrm{n}$ & 6.60 & 64.2 & 90.7 & 62.2 & 79.6 & 68.7 & AA \\
\hline $\mathrm{T}-21$ to 28 & $\mathrm{~m}$ & 5.38 & 80.6 & $\ldots$ & 75.7 & 96.3 & 84.2 & AA \\
\hline $\mathrm{T}-31$ to 38 & $\mathrm{n}$ & 5.55 & 70.0 & $\ldots$ & 79.4 & 93.9 & 81.1 & A A \\
\hline T-41 to 48 & $\mathrm{~m}$ & 6.09 & 70.7 & .... & 65.6 & 88.4 & 74.9 & AA \\
\hline T-51 to 58 & $\mathrm{n}$ & 5.90 & 68.9 & ...... & 66. 9 & 82.5 & 72.8 & A \\
\hline T-61 to $68 \ldots$ & $\mathrm{m}$ & 6.55 & 59.8 & ..... & 53.9 & 61.8 & 58.5 & AA \\
\hline T-71 to 78 & $\mathrm{n}$ & 6.56 & 54.9 & 77.6 & 63.1 & 68.3 & 70.5 & $\mathrm{AA}$ \\
\hline Avg... & & & 65.6 & $\therefore$ & 64.3 & 78.4 & 69.4 & \\
\hline
\end{tabular}

BLACK, GLOSSY, NONACID-RESISTANT ENAMEL

\begin{tabular}{|c|c|c|c|c|c|c|c|c|}
\hline $\mathrm{V}-1$ to $8 \ldots \ldots$ & $\mathrm{n}$ & 5.52 & 63.6 & - - & 59.8 & 36.8 & 53.4 & $\mathrm{C}$ \\
\hline $\mathrm{V}-11$ to 18 & a & 5. 62 & 57.0 & $\ldots$ & 51.8 & 43.9 & 50.6 & $\mathrm{C}$ \\
\hline $\mathrm{V}-21$ to $28 \ldots$ & $\mathrm{n}$ & 5. 76 & 58.8 & - n-..- & 61.8 & 41.2 & 53.9 & $\mathrm{C}$ \\
\hline $\mathrm{V}-31$ to 38 & a & 5. 60 & 40.1 & - n & 40.5 & 43.3 & 41.3 & $\mathrm{C}$ \\
\hline $\mathrm{V}-41$ to 48 & $\mathrm{n}$ & 5.30 & 59.7 & 77.4 & 67.2 & 43.8 & 56.9 & $\mathrm{C}$ \\
\hline V-51 to 58 & a & 5.49 & 58.0 & - & 65.5 & 40.4 & 54.6 & $\mathrm{C}$ \\
\hline $\mathrm{V}-61$ to $68 \ldots$ & $\mathrm{n}$ & 4. 67 & 75.9 & (n.... & 58.9 & 67.0 & 67.3 & $\mathrm{C}$ \\
\hline V-71 to $78 \ldots$ & a & 5.45 & 73.9 & & 70.1 & 65.8 & 69.9 & $\mathrm{C}$ \\
\hline Avg ... & & & 60.9 & & 59.4 & 47.8 & 56.0 & \\
\hline
\end{tabular}

1 Groups of 8 panels exposed, 2 at each location. Ninth panel kept in storage.

${ }^{2}$ Cleaned by nonstandard procedure of prolonged scrubbing with commercial scouring powder.
3 Values are average of 2 panels with 2 readings on each panel.

4 Test made on storage panel according to Porcelain Enamel Institute standard acid-resistant spot test for flatware issued April, 1940.

${ }^{5}$ Full-mat enamels, initial gloss too low for measurement. 


\section{Panels at St. Louis, Mo.}

The 192 panels at the St. Louis location (on a roof near a railway terminal) were found to have a dark gray deposit over the entire surface, which was sufficiently heavy to make all panels have approximately the same appearance, regardless of their original color or gloss. An examination showed this deposit to consist of fly ash, soot, and a tar-like substance. A small sample scraped from the surface of one panel of high acid resistance showed an ignition loss of 31 percent, indicating that the greater part of the deposit (69 percent) consisted of the noncombustible fly ash. The deposit originated from soft-coal combustion products that were present in high concentration in the exposure area.

The standardized cleaning procedure of washing with 1-percent trisodium-phosphate solution did not remove this deposit, and vigorous scrubbing with a scouring powder was the only method found to give satisfactory cleaning. Unfortunately, this scrubbing had a polishing action that affected the gloss measurements and vitiated their reliability as a criterion of the degree of weathering.

The aluminum paint on the steel supporting racks had deteriorated badly at the St. Louis location, but corrosion of the steel was not as yet pronounced. The previously mentioned deposit was also present on the steel racks and may have had a protective influence in decreasing the corrosion rate.

\section{Panels at Lakeland, Fla.}

Tiny patches of an organic growth were attached to all panels at the Lakeland exposure site. The patches were largest and most numerous on the white enamels, but the black panels also showed some evidence of the growth. The patches adhered tightly to the enamel surface but could be removed by vigorous washing with a wet rag. When dry, the patches were gray but when thoroughly wetted they became green or, in some cases, brown.

An examination of these patches was made at the Florida Agricultural Experiment Station at Lake Wales. Under the microscope the patches appeared as clusters of oval-shaped fungus spores with occasional algae growth present, especially on the white panels.

On many of the nonacid resistant enamels, there were areas having much higher gloss than the remainder of the surface. Examination showed these areas to be substantially free of the growth, indicating that these organisms produced an acid reaction that accelerated the deterioration of the enamel surface. None of the panels with acid resistance of class B or better showed this localized etching

Jones [4], in explaining the behavior of optical glass elements used in the tropics, states that fungi produce organic acids that etch glasses subject to acid attack.

Corrosion of the steel racks was only moderate at the Lakeland location. The aluminum paint had deteriorated but rusting was not serious.

\section{Panels at Atlantic City, N. J.}

At Atlantic City, damage to the installation was considerable and was caused by a combination of factors including the following: (1) The 1944 hurricane that struck the site with full intensity, (2) moving of the racks to make room for wartime expansion at the Coast Guard Station, (3) the location in 1943 of a Navy athletic field immediately adjacent to the exposure site, and (4) the corrosive action of salt air on the steel. Nine of the panels were missing, and seven others had become detached from the mounting and were on the ground. Many of the panels had been damaged by impact, probably caused by stones thrown from the adjacent athletic field. Nevertheless, surface measurements were possible on practically all of the panels.

Observations at this site indicated that both the paint and galvanizing failed rapidly under the salt-air conditions. Corrosion had seriously damaged the painted steel racks and the galvanized channels were, in many cases, so rusted that replacement was necessary.

The top attachment clips ( $C$ in fig. 2 ) had become detached on some of the panels. These clips had been spot-welded to the panels prior to enameling, and, in some cases, this joint was protected only by a thin ground coat application. On many of the clips this thin coat was insufficient to give complete coverage where the clip joined the panel, and the severely corrosive conditions had caused failure.

This severe corrosion of the metal at Atlantic City was also responsible for a somewhat unexpected type of damage to the enamel surface resulting from poor enamel coverage of the backs 
of panels. On those panels that had been covered on the reverse side with only a ground coat and then fired in a box furnace while resting on alloy points, poor coverage of the steel occurred at the contact points. Corrosion had started at these areas and had, in some cases, progressed completely through the 16-gage steel to the under surface of the enamel on the face side. Fracture of the enamel on the face immediately above these areas occurred as the corrosion approached the enamelmetal interface. The resulting fractures resembled very large fish scales and were believed to have been caused by hydrogen generated during the corrosion process. That hydrogen diffusing through steel may literally explode the enamel from the opposite surface had been demonstrated previously by Zapffe and Sims [5]. The fact that a number of "fish-scale" type fractures were noted on the faces of panels over localized corrosion areas while some metal still remained beneath indicates that the fractures could not have been caused by the forcing off of the enamel by corrosion products, nor could they be caused by buckling of the enamel due to the release of compressive strains resulting from a small area of the underlying metal being removed by corrosion.

Figure 3 shows the face of a panel that was damaged by corrosion originating from firing marks on the reverse side. Several holes and also a number of the previously described fractures are apparent on this specimen. It should be pointed out, however, that these defects did not occur on the panels that had been given a thin second coat of enamel on the reverse side, nor had corrosion progressed to this extent at any location except Atlantic City.

Another type of surface defect, noted only at Atlantic City, was a type of staining that invariably appeared on the enamel surface adjacent to any damaged area that exposed the metal. These stains appeared as iridescent films and were believed to be analogous to the iron stain on glass containers described previously by Marboe and Weyl [6]. These investigators found that staining of wet glass in contact with iron results from the interreaction of positively charged ferrous ions with the glass surface, thus leading through oxidation to the formation of an insoluble, colored ferric hydrosilicate. In this study, gloss measurements on areas showing these stains gave exceptionally high readings.

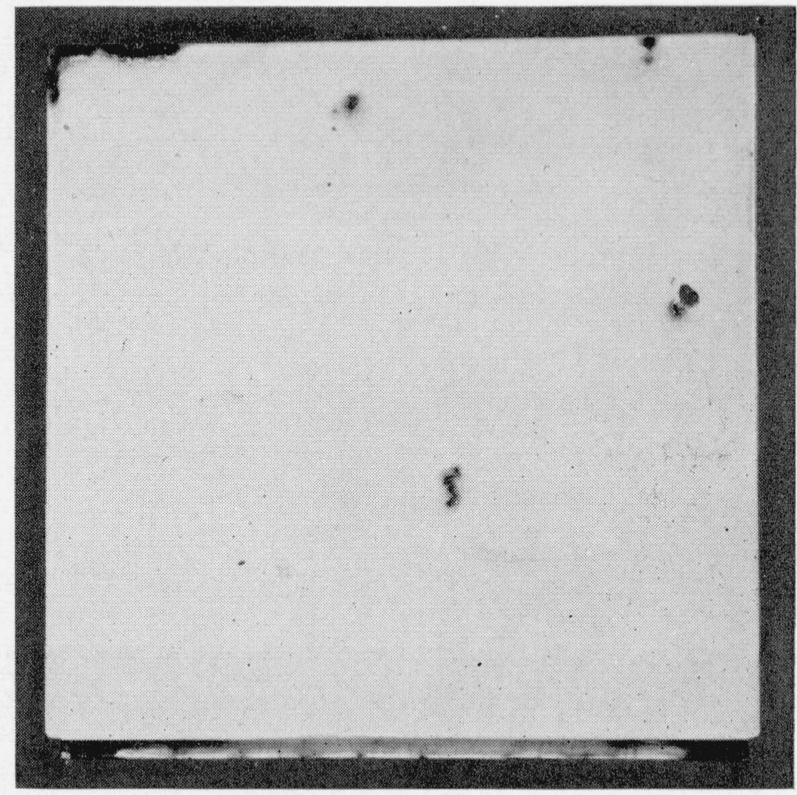

Figure 3. Panel A-58 after 7 yr of exposure in the salt air at Atlantic City, N.J.

Surface defects, including hole at right center, were caused by rusting through from areas of incomplete coverage on the back of panel. Specimens with a thin second coat of enamel on the reverse side were not affected in this way.

Numerous tiny localized areas of iron staining were also noted on many of the Atlantic City panels. Close examination of these patches showed tiny pin holes at the centers, which were allowing corrosion of the metal.

\section{Surface Changes Resulting From 7 Years of Weathering}

Reference has been made in the preceding section to corrosion of the steel where it was not adequately covered by enamel. This part of the report pertains to changes that occurred as a result of weathering on the enamel surfaces where coverage was complete.

\section{Microstructure}

As shown in figures 4 and 5, photomicrographs taken with a metallographic microscope indicated practically no change from the original surface microstructure of the enamels with high acid resistance after 1 and 7 yr of weathering. Enamels of poor acid resistance, on the other hand, showed considerable progressive deterioration. The "pits" on most of these enamels (illustrated by several photomicrographs in the first report [3]) were no longer a characteristic feature of the microstruc- 

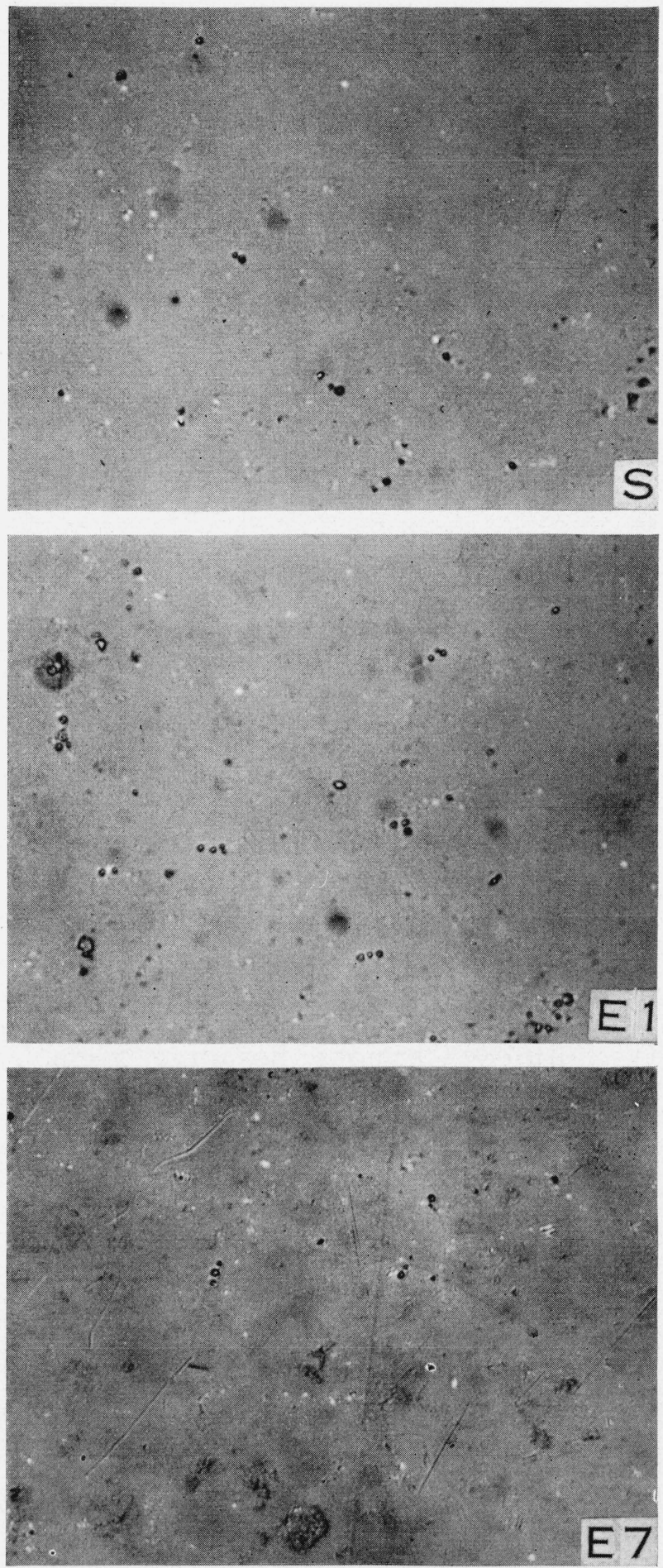

Figure 4. Photomicrograph $(\times 600)$ of typical black, glossy, acid-resisting enamel showing no fundamental change in microstructure with progressive weathering.

$\mathrm{S}$ is storage panel, T-69. E-1 and E-7 show areas on a duplicate panel, $T$-61, after exposure for 1 and $7 \mathrm{yr}$, respectively, in Washington, D. C. Specks are probably mill additions.
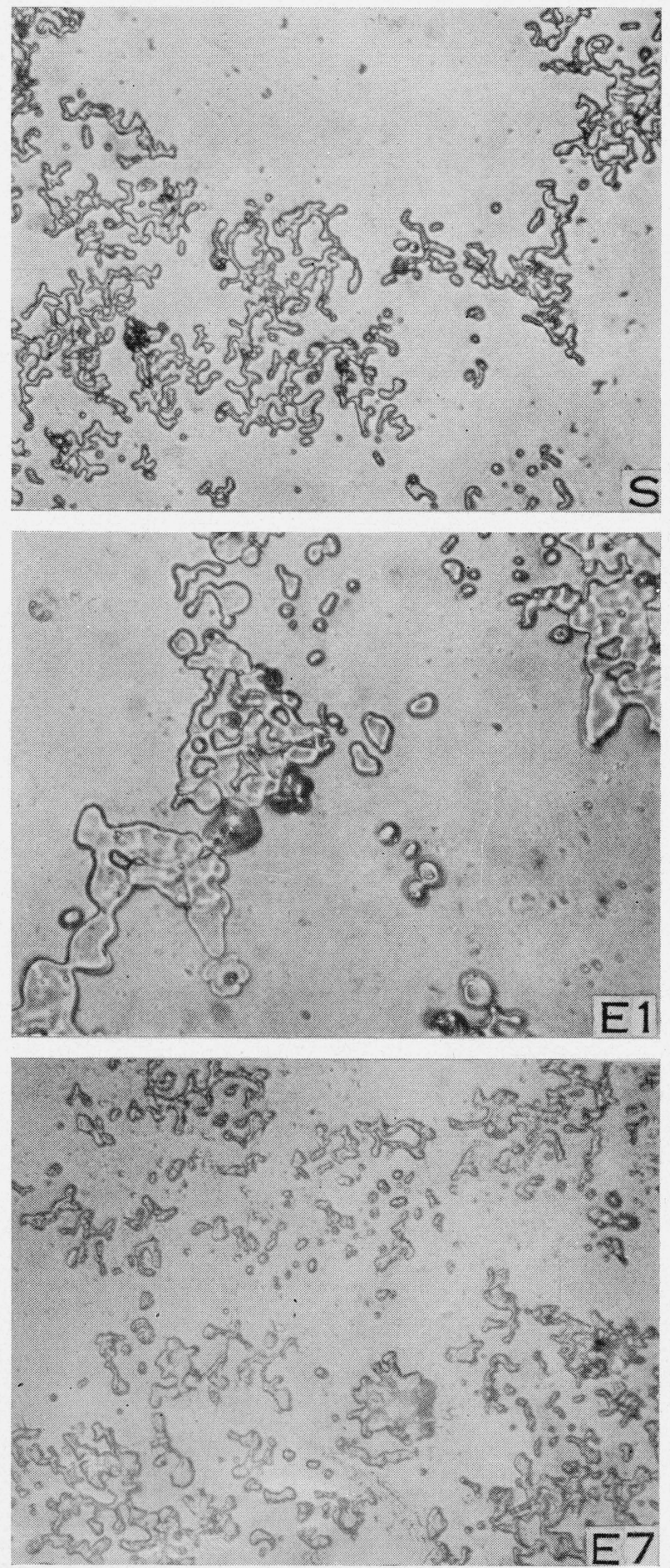

Figure 5. Photomicrograph $(\times 600)$ of a red, semimat enamel of good acid resistance, showing no appreciable change in surface microstructure from weathering during a 7 -yr period.

S, storage panel, P-49. E-1 and E-7 show areas on a duplicate panels $P-41$, exposed for 1 and $7 \mathrm{yr}$, respectively, in Washington, D. C. Particles exposed at surface are undissolved material added to give a mat finish. The difference in size of the exposed particles is not considered significant. 

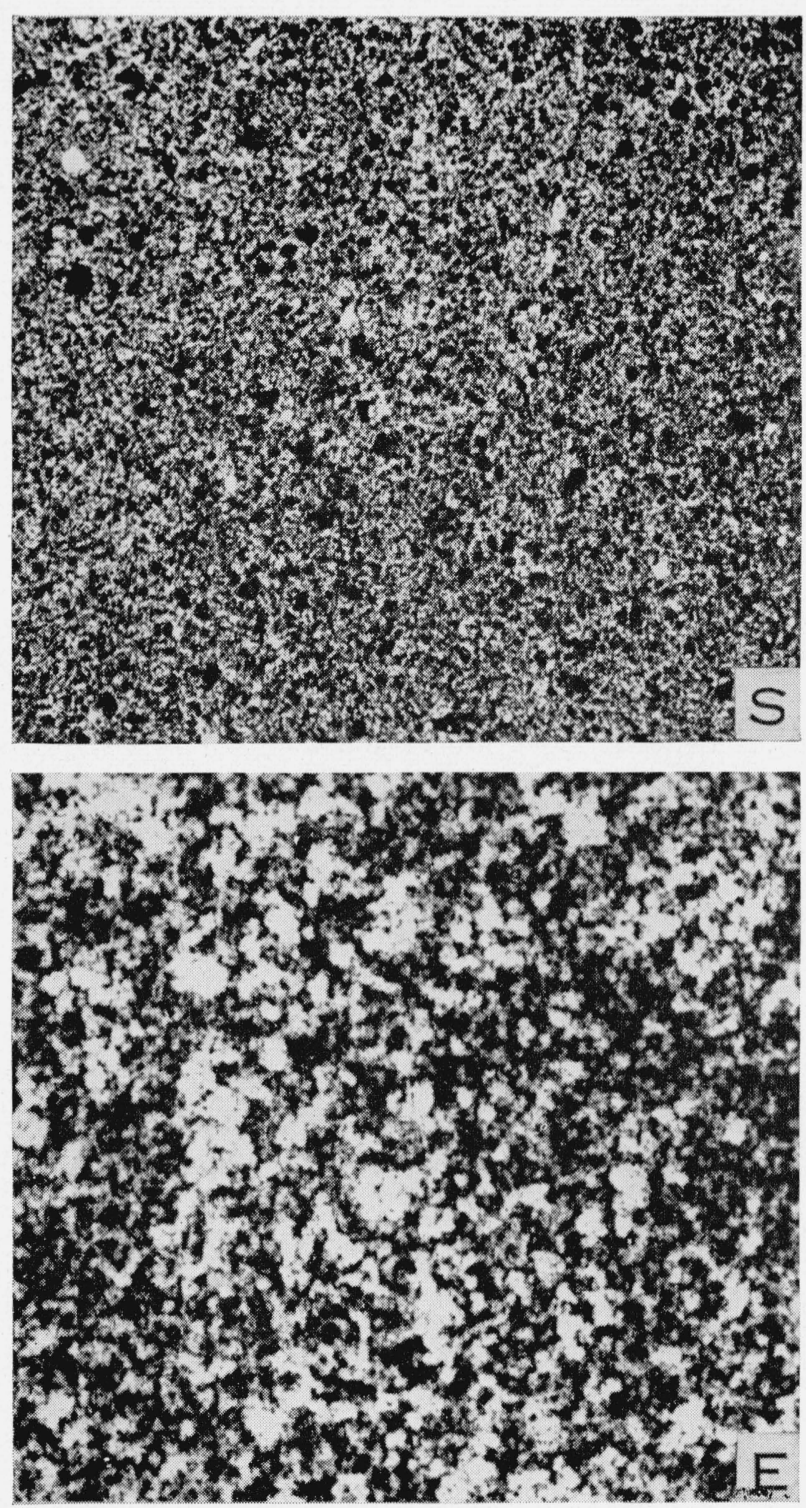

Figure 6. Photomicrograph $(\times 20)$ of a black, nonacid

resisting enamel showing large surface change after $7 y$ of weathering.

$\mathrm{S}$ is storage panel, $\mathrm{V}-19$. $\mathrm{E}$ is duplicate panel, $\mathrm{V}-11$, exposed $7 \mathrm{yr}$ in Washington, D. C. Large light areas in $\mathrm{E}$ are alteration products resulting from a chemical change in the surface layer.

ture, and deterioration of the surface had progressed considerably beyond the pitting stage. Two examples of these enamels are illustrated in figures 6 and 7 .

The photomicrographs in figure 6 provide a comparison between the storage panel $(\mathrm{V}-19)$ and the duplicate panel $(\mathrm{V}-11)$ after 7 yrs of weathering. The surface in the photomicrograph of $\mathrm{V}-11$ is that of a relatively heavy gel layer, which formed during the 7-yr exposure. This gel is apparently a hydrated layer, rich in silica, resulting from the leaching of soluble constituents from the enamel surface. The layer was much softer than the underlying enamel and could be scraped from the surface with a sharp blade.
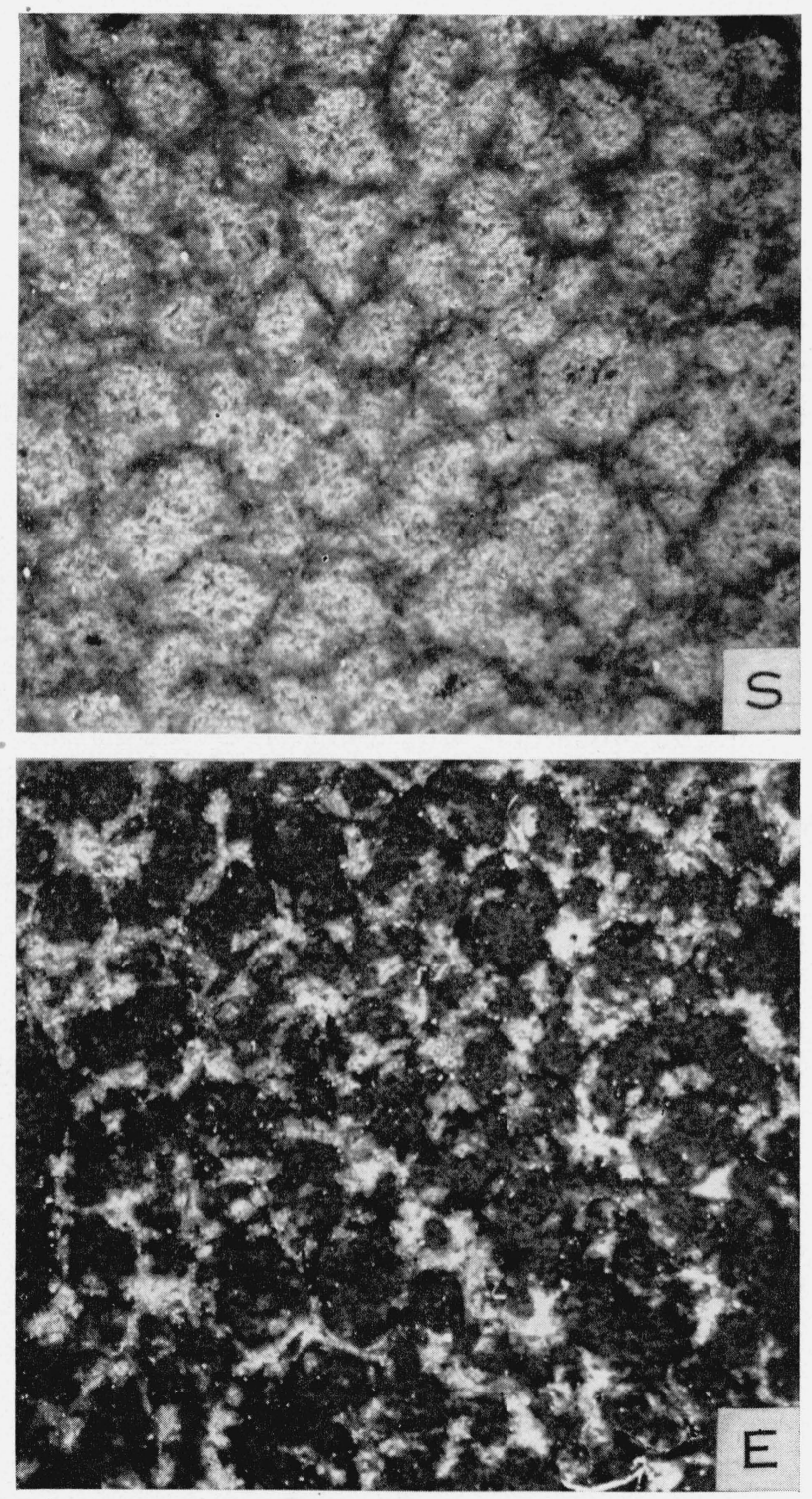

Figure 7. Photomicrograph $(\times 20)$ of a red, nonacidresistant, semimat enamel prepared with a two-frit combination showing a grain boundary type of disintegration after weathering.

S is storage panel $P-29$. E is duplicate panel $\mathrm{P}-22$ after exposure for $7 \mathrm{yr}$ at Washington, D. C. Dark gray material surrounding lighter colored grains in $\mathrm{S}$ is made up of the more fusible of the two enamel frits This more fusible frit shows greater weathering effects and appears as a light materia bounding darker grains in $\mathrm{E}$. This light material appears under the microscope to be shattered. 
Thickness measurements, as made with a magnetic thickness gage, before and after scraping, indicated a gel layer of $0.0008 \mathrm{in}$. on the Washington panel, $\mathrm{V}-11$, and $0.0012 \mathrm{in}$. on the St. Louis panel, V-15. The surface film on all $\mathrm{V}-11$ to $\mathrm{V}-18$ panels had a vitreous texture and still retained an average of 50.6 percent of the initial gloss. Fading was pronounced on these panels at all locations, the color changing from black when first installed to a light gray after 7 yrs.

A portion of the gel-like layer was scraped from the St. Louis panel, V-15, after cleaning. The ignition loss of the scrapings upon heating to $1,650^{\circ} \mathrm{F}$ was 23.4 percent. The material after heating was a brown, partially sintered powder having no resemblance to a porcelain enamel. The loss in weight of the heated material was believed to be due almost entirely to loss of water.

The photomicrograph of panel $P-22$ (fig. 7) shows a peculiar type of surface break-down. The original enamel was a glossy red of class C acid resistance. ${ }^{2}$ According to the frit manufacturer, the enamel represented by panels $\mathrm{P}-21$ to $\mathrm{P}-28$ was prepared from a two-frit combination. From the results obtained it is apparent that one of the frits was much more resistant to weathering than the other, and the two frits did not blend during firing into a homogeneous glass. The frit of poor weather resistance is shown by the light areas in figure 7, E, which appear in figure 7 , S, as dark boundaries to the relatively large grains. Another enamel (panels $\mathrm{P}-31$ to $\mathrm{P}-38$ ) prepared from the same frits, but applied by a different fabricator, did not show this effect. In this case the enamel may have been more finely ground and fired for a longer time.

\section{Fading}

Observations of color difference made on all panels during the 7-yr inspection indicated that:

2 Test for Acid Resistance of Porcelain Enamels; Part r-Flatware. Issued by the Porcelain Enamel Institute, 1010. Vermont Ave., NW., Washington, D. C. In the commercial test, which separates enamel according to classes, a small pool of 10-percent citric acid is placed on the specimen for $15 \mathrm{~min}$ at $80^{\circ} \mathrm{F}$. The degree of attack is then evaluated by visual methods by using such characteristics as visuel strain, blurring of image, and ease of removal of a pencil mark. Class AA shows no visible effect from the treatment and is the most resistant, with class A, class B, class C, and class D following in that order. Enamels falling in the latter two classes are not considered as acid resistant.

A research test for acid resistance is included in the same pamphlet. The research test is quantitative in that the loss of $45^{\circ}$ specular gloss is measured for each sfecimen after a 15-min immersion in the 10-percent citirc acid at $89^{\circ} \mathrm{F}$.
1. No colored enamel of class AA or A by the Porcelain Enamel Institute acid-resistance test (see footnote 2) showed any noticeable change in color.

2. No colored enamel of class B acid resistance showed any objectionable fading.

3. Practically all deeply colored enamels of classes C and D acid resistance showed color change, and in most cases this fading was sufficiently pronounced to be considered objectionable.

4. The colored full-mat enamels that showed pronounced fading at the end of the first year did not change much in appearance during the next 6 yrs.

5. Fading of the colored enamels of poor acid resistance was almost equally pronounced at all four exposure locations, even beneath the surface deposit that formed at St. Louis.

Reflectance measurements for color difference were not attempted at the $7-y r$ inspection. Determinations of this type are currently under study, and it was believed that color difference data taken at the time of the inspection would be of questionable value. A standard method of measuring color difference is expected to be established in time for the 10-yr inspection in 1950, at which time quantitative comparisons of stored panels and exposed panels may be made.

\section{Specular Gloss}

Specular-gloss measurements were made on each panel at the exposure site, by using the Hunter Multipurpose Reflectometer [7] adjusted for a $45^{\circ}$ angle of incidence. Measurements were made at two fixed locations near the center of the panel immediately after the cleaning operation, which consisted of (a) washing with a warm 1-percent solution of trisodium phosphate, (b) thoroughly rinsing with tap water, and (c) drying in air. The initial gloss measurements were standardized against a liquid film [8]. The 7-yr data were obtained with the same multipurpose reflectometer and with the same liquid-film standards.

The changes in $45^{\circ}$ specular gloss that had occurred at the end of $7 \mathrm{yr}$ of weathering are summarized in table 3 . The values as given for Washington, Lakeland, and Atlantic City are for the most part complete, but only a few representative values are reported for St. Louis. The St. Louis measurements were all made on surfaces 
that had been cleaned by the nonstandard procedure of a vigorous and prolonged scouring, which in effect constituted a polishing action that affected the gloss and thus invalidated the gloss measurements on these specimens.

In general, it was noted that the $45^{\circ}$ surface gloss changed at a faster rate in the earlier stages of exposure than later. Figure 8 illustrates this effect for three Washington panels that were chosen as being representative. In all three panels there was considerably more change during the first 3 years than during the next 4 , and in the case of panel $\mathrm{F}-11$, there was more change during the first year than during the next 6 .

The relation between acid resistance and weather resistance, as measured by the percentage of initial specular gloss retained, is given in table 4 . It will be noted that there is a direct correlation between the class of acid resistance by the PEI commercial test (see footnote 2) and the average percentage of gloss retained.

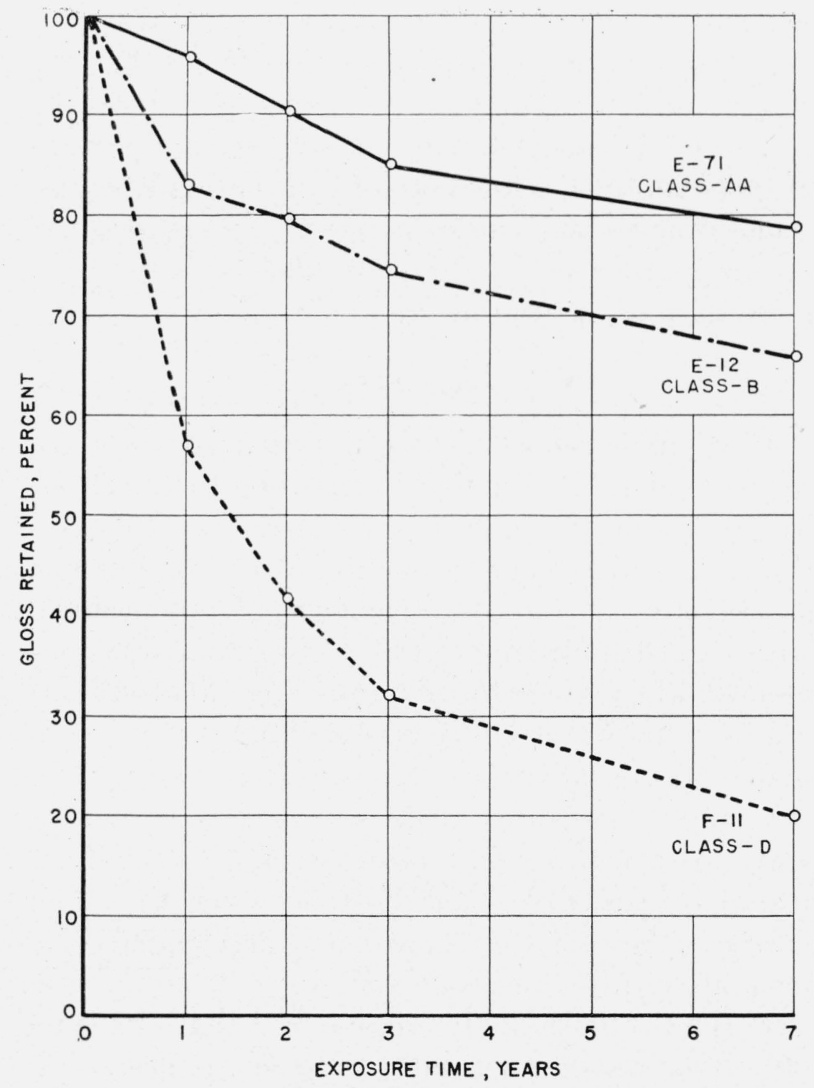

Figure 8. Curves showing decrease in percentage of gloss retained with increasing exposure time for three typical panels exposed at Washington, D. C.
TABLE 4. Summary of gloss data showing the average percentage of specular gloss retained after 7 years of weathering for various classes of acid resistance

\begin{tabular}{|c|c|c|c|c|c|}
\hline \multirow{2}{*}{$\begin{array}{l}\text { Number of } \\
\text { enameis } \\
\text { averaged } 1\end{array}$} & \multirow{2}{*}{$\begin{array}{l}\text { Acid re- } \\
\text { sistance } \\
\text { class }^{2}\end{array}$} & \multicolumn{4}{|c|}{$\begin{array}{c}\text { A verage percent of initial specular gloss } \\
\text { retained }{ }^{3} \text { at- }\end{array}$} \\
\hline & & $\begin{array}{l}\text { Wash- } \\
\text { ington }\end{array}$ & $\begin{array}{l}\text { Lake- } \\
\text { land }\end{array}$ & $\underset{\text { City }}{\text { Atlantic }}$ & $\begin{array}{l}\text { A verage } \\
\text { at three } \\
\text { locations }\end{array}$ \\
\hline $29 \ldots$ & $\mathrm{AA}$ & 73.3 & 81.6 & 69.6 & 74.8 \\
\hline $15_{\ldots}$ & $\mathrm{A}$ & 69.7 & 70.0 & 62.3 & 67.3 \\
\hline $3 \ldots$ & B & 70. 7 & 64.2 & 50.2 & 61.7 \\
\hline $24 \ldots$ & $\mathrm{C}$ & 54.9 & 43.1 & 52.8 & 50.3 \\
\hline $16 \ldots$ & $\mathrm{D}$ & 44.4 & 36.0 & 46.3 & 42. 2 \\
\hline
\end{tabular}

1 Each enamel represented by 2 panels at each location.

From spot tests made on 12- by 12 -in. storage panels, using the porcelain Enamel Institute standard acid-resistance spot test for flatware.

3 Percentage of gloss retained for St. Louis panels not included because tightly adhering surface deposits made gloss measurements unreliable.

The results at Lakeland showed the same excellent correlation between the class of acid resistance and gloss retention that was shown by the average. At Washington and Atlantic City there was a reversal of two values, involving class $\mathrm{B}$ enamels in both instances. Only three class B enamels were included in the investigation. If more enamels of this class had been included a better average value would have been obtained and these reversals might not have occurred.

Table 4 shows only moderate differences in the perentage gloss retained at the three locations after $7 \mathrm{yr}$ of exposure. The class $\mathrm{AA}$ and class $\mathrm{A}$ enamels were somewhat more affected by the conditions existing at Atlantic City than at Washington and Lakeland. On the other hand, the semitropical conditions at Lakeland and the accompanying fungus growth appear to have produced more surface deterioration on class $\mathrm{C}$ and class D enamels.

\section{Effectiveness of Scouring in Restoring Gloss}

The effectiveness of scouring with a commercial cleanser ${ }^{3}$ in restoring gloss to two weathered panels was investigated during the Lakeland inspection. A red, nonacid resistant panel (N54) was found to increase from 52.8-percent gloss

\footnotetext{
${ }^{3}$ Examination showed the cleansing powder to consist of finely ground feldspar with a soap admixture.
} 
retained after trisodium phosphate cleaning to 60.4 percent after $5 \mathrm{~min}$ of scouring with the powder. A red, acid-resistant composition (panel $\mathrm{L}-13)$ on the other hand, decreased from 96.5 to 88.3 percent. Indications were that a more prolonged rubbing with the commercial scouring powder did not materially change these values. The continued, severe scouring required to clean the surface deposit from the St. Louis panels, on the other hand, showed a polishing action that raised the gloss readings of some of the enamels of better acid resistance to even higher than their initial values (see table 3 ).

\section{Accelerated Weathering Tests}

In the earlier report [3] reference was made to a carbon dioxide test that produced a type of surface breakdown of the finish coat closely related to the deterioration that occurred with the poorer enamels during the first year of weathering. Gloss measurements made before and after the

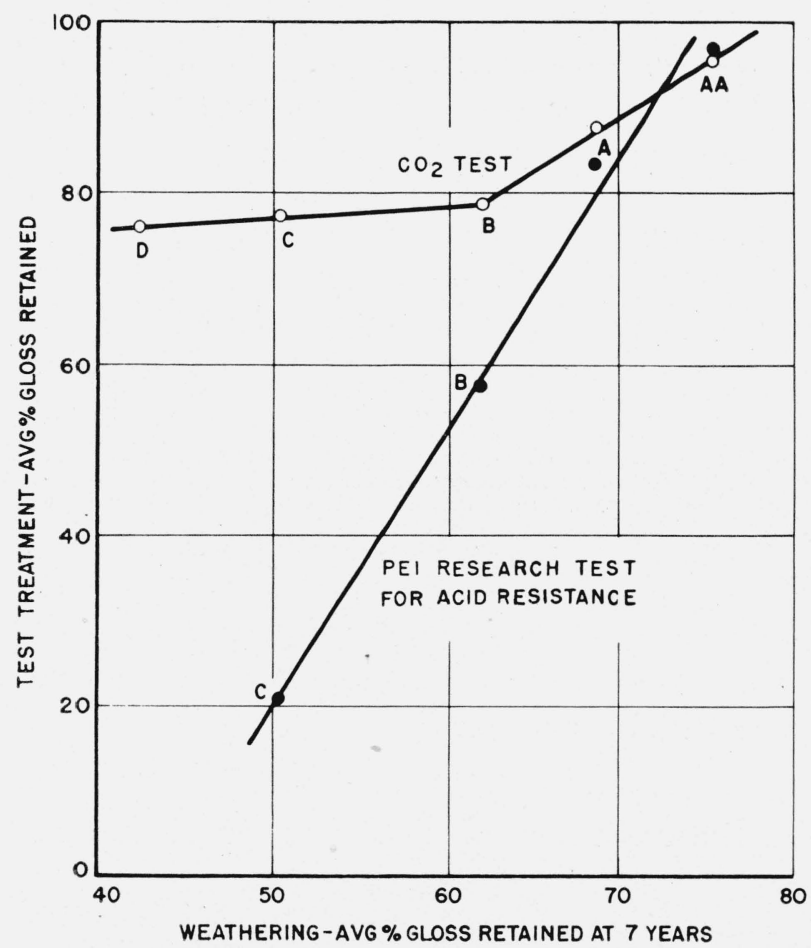

Figure 9. Curves showing relationship between the average percertage of gloss retained after weathering ard the percentage of gloss retained after treatment of duplicate specimens by both the $\mathrm{CO}^{2}$ test and the PEI research test for acid resistance.

Let ters on curves show class of acid resistance by PEI spot test. The gloss values for class D enamels were too low for measurement after the PEI research test treatment. carbon dioxide treatment gave gloss-retention values that correlated well with the percentage of gloss retained by the exposed panels.

It was hoped that this correlation might continue with a more prolonged exposure of the panels, but the results of the 7-yr inspection indicated that the carbon dioxide test is not a sensitive criterion for predicting the durability of an enamel exposed to weather. As presently constituted, the test does not sufficiently differentiate between the best and the poorest enamels. This is brought out in figure 9, which shows the relationship between the average percentage of gloss retained by the weathered panels after $7 \mathrm{yr}$ and the average percentage of gloss retained after treating the duplicate laboratory specimens in accordance with the carbon dioxide test and with the Porcelain Enamel Institute research test for acid resistance. It will be noted from these curves that the $7-y r$ resistance to weathering has a considerably better correlation with the PEI research test for acid resistance (see footnote 2) than with the carbon dioxide test.

As pointed out earlier in section IV, 3, the PEI commercial test for acid resistance (see footnote 2) also correlates well with the average percentage of gloss retained after $7 \mathrm{yr}$ of weathering and can undoubtedly continue to function satisfactorily as an acceptance test until such time as more complete data are available.

\section{Discussion}

In the first report of this investigation [3] there was considerable discussion regarding the mechanism by which porcelain enamel surfaces are affected by weathering. The inspection after $7 \mathrm{yr}$ has not appreciably altered these concepts except perhaps with regard to pitting. The pitting that was previously illustrated by a number of photomicrographs is now recognized as being only an early manifestation of surface deterioration. On longer exposure, these same surfaces show an advanced stage of attack, an extreme case of which is illustrated by panels $\mathrm{V}-11$ to $\mathrm{V}-18$ (see fig. 6 ). The entire surface of the enamel on these panels has been altered by chemical change.

It should be strongly emphasized that the type of surface breakdown referred to in the preceding paragraph occurs only on those enamels of extremely poor weather resistance, which can be 
eliminated from use by the criterion of acid resistance. All enamels of class B acid resistance or better were still in excellent condition at the latest inspection.

At the end of the first year of exposure, it was noted that weathering effects were more pronounced at St. Louis and Washington than at Atlantic City and Lakeland, and this was ascribed to differences in combustion gases in the respective atmospheres. At $7 \mathrm{yr}$, these differences in severity were no longer in the same order. After the longer exposure time, conditions at Atlantic City seemed the most severe on the acidresistant enamels, whereas Lakeland conditions were most severe on the nonacid resistant compositions. The deposit that formed on the St. Louis panels made a reliable comparison with the other exposure sites impossible. Any future tests in such areas should include arrangements for at least semiannual cleaning of the specimens.

The cause of the gradual decrease in gloss of the enamel surfaces with weathering, as illustrated in figure 8 , is believed to be a slow leaching of slightly soluble constituents from the enamel surface, leaving a gel-like layer rich in silica. The rate at which this alteration occurs is a function of the composition of the enamel and the conditions to which the surface is exposed. After $7 \mathrm{yr}$, the thickness of the altered layer may be comparatively heavy (up to $0.0012 \mathrm{in}$. thick), as is the case with enamel $\mathrm{V}-11$ to $\mathrm{V}-18$, or it may be very thin on the enamels of high acid resistance.

This same type of surface deterioration also occurs with glass. According to Jones [4], when glasses containing less than 60 percent of silica are subjected to weathering, the divalent ions from the glass surface go into solution and are replaced by hydrogen ions from weakly acid water, thus resulting in a hydrated-silica surface layer. That glasses of higher silica content also may show this same gel formation on longer exposure is shown by Laubengayer [9] in his study of a sodalime-silica glass (66.5 percent of silicon dioxide) that was entombed in a burial vault in Cyprus for approximately 1,800 yr. Laubengayer found that this glass was incrusted with a white flaky material that consisted mainly of hydrated silica. Also, other investigators [10] have found indications of the presence of a gel layer on old window glass and old glass tubing.

Fading of the colored enamels with poor acid resistance is also probably caused by the leaching and subsequent hydration of the surface layer. The resulting hydrated film on colored enamels usually assumes a lighter color than the original surface and gives a faded appearance to the panels. The degree of color change depends on the thickness and composition of the film and on the original color of the enamel. Unlike the panels studied by Sweo [11], in this investigation enamels having the deeper colors, rather than the pastel shades, showed the maximum color change. The etching at the bottom edges of the panels, as reported by Sweo, was noted on a few panels at Lakeland. The method of mounting the panels was such as to prevent water from collecting in pockets, but the heavy rainfall at Lakeland (see table 2), together with the resulting high humidity, probably allowed water to remain along the bottom edge for prolonged periods during humid weather.

Protection of the surface of nonacid-resistant colored enamels by a very thin application of a clear overglaze enamel has proved only moderately successful. In the earlier report [3] this method of protecting the surface appeared to show marked promise, but after $7 \mathrm{yr}$, surface pits had begun to appear in several of these overglazed surfaces. Heavier applications of the overglaze would undoubtedly overcome this weakness.

One of the more important observations made during the 7-yr inspection was the great importance of good enamel coverage when panels are exposed to salt air. The salt air conditions at the exposure site at Atlantic City are probably more severe than at most seacoast installations, and in commercial practice the reverse sides of the panels, where corrosion began, would not be exposed as they were in this investigation. It is the authors' recommendations that on all seacoast installations, special care be taken to insure complete enamel coverage of the backs of panels and attachment lugs. The same precaution should probably also be followed on tropical or subtropical units, and as an engineering safety factor the practice could well be universal.

A discussion of the mechanism of weathering naturally results in bringing to the fore the enamels of relatively poor weather resistance. The important fact is, however, that enamels of good acid resistance, applied to obtain good coverage, were still in very good condition in all locations after 7 yr. Hudson and Banfield [12] working in Eng- 
land, also found acid-resistant enamels to be in excellent condition after $5 \mathrm{yr}$ in industrial or nonindustrial atmospheres, or after 2 yr submerged in sea water.

On the basis of both the 1-yr and the 7-yr data, the authors feel that the recommendations as made in the earlier report continue to be valid. These recommendations were:

1. Where appearance is an important factor, full-mat enamels of the type included in this investigation should not be used for outside installations, as they tend to accumulate and retain a dingy film and to fade.

2. Enamels of acid resistance less than class B (PEI test) should not be used in any architectural installation where general appearance and absence of fading are important. An acid resistance of class $\mathrm{A}$ or class $\mathrm{AA}$ is to be preferred.

\section{Summary}

A second inspection of the 784 1-ft.-sq. porcelain enameled panels of varying types exposed at Washington, D. C., St. Louis, Mo., Lakeland, Fla., and Atlantic City, N. J. was completed during 1947. The observations made during this inspection, which represents $7 \mathrm{yr}$ of exposure, may be summarized as follows:

1. Good correlation existed between acid resistance and the percentage of initial gloss retained, the enamels of best acid resistance retaining the highest percentage of their original gloss.

2. No noticeable fading of enamels of class AA or class $\mathrm{A}$ acid resistance occurred, nor was there objectionable fading of class $\mathrm{B}$ enamels. Practically all class $\mathrm{C}$ and class $\mathrm{D}$ colored enamels, however, showed very noticeable color change.

3. In contrast to the results of the first-year inspection, which showed greatest weathering effects at St. Louis and Washington, the 7-yr data indicate that the conditions at Atlantic City were slightly more severe than elsewhere on the acid-resistant enamels, whereas Lakeland conditions were most severe on the nonacid-resistant compositions.

4. The salt-air conditions at Atlantic City caused considerable corrosion of those parts of the panels that were incompletely covered by enamel. This corrosion caused failure of attachment lugs and in some cases failure of enamel on the face by rusting through to near the enamel-metal interface from areas of poor coverage on the back.
Specimens with a thin second coat of enamel on the back were not affected in this way.

5. Where the initial coverage was complete on all parts of the panel and where no mechanical damage had occurred during exposure, protection of the metal against corrosion was unimpaired on all specimens after $7 \mathrm{yr}$ of weathering.

This study was made possible by the cooperation of the following companies in supplying the necessary enamel frits and specimens for the study:

Baltimore Enamel \& Novel- Ingram-Richardson Mfg. ty Co.

W. A. Barrows Porcelain Pemco Corporation. Enamel Co.

Chicago Vitreous Enamel Product Co.

Davidson Enamel Products Co.

Erie Enameling Co.

Ferro Enamel Corporation.

General Porcelain Enameling \& Mfg. Co.

Porcelain Metals Corp.

Porcelain Products Co

Seaporcel Corp.

J. M. Seasholtz \& Sons.

Texlite, Inc.

Toledo Porcelain Enamel Products Co.

Wolverine Porcelain Enameling $\mathrm{Co}$.

Acknowledgment is made also to the Porcelain Enamel Institute, whose financial contribution to the installation and inspection of the specimens has been most helpful in carrying the work toward completion.

The advisory committee, which offered much valuable assistance in selecting the types of enamel for study and planning the investigation, consisted of P. H. Bates, E. C. Greenstreet, J. I. Irwin, P. B. McBride, Paul Seasholtz, J. D. Tetrick, and H. G. Wolfram.

\section{References}

[1] C. G. Straundlund, E. Olsen, and E. E. Howe, Finish 5, L1 (1948).

[2] C. T. Post, Iron Age 15\%, 110 (1946).

[3] W. N. Harrison and D. G. Moore, J. Research NBS 28, 735 (1942) RP1476.

[4] F. L. Jones, J. Am. Ceram. Soc. 28, 32 (1945).

[5] C. A. Zapffe and C. E. Sims, J. Am. Ceram. Soc. 23, 192 (1940)

[6] E. C. Marboe and W. A. Weyl, J. Am. Ceram. Soc. 30, 320 (1947).

[7] R. S. Hunter, J. Research NBS 25, 581 (1940) RP1345.

[8] D. G. Moore and R. S. Hunter, J. Am. Ceram. Soc. 24, 167 (1941).

[9] A. W. Laubengayer, J. Am. Ceram. Soc. 14, 833 (1931).

[10] J. W. Mellor, Trans. Eng. Ceram. Soc. 34, 113 (1934).

[11] B. J. Sweo, The Enamelist 18, 13 (1940).

[12] J. C. Hudson and T. A. Banfield, J. Iron Steel Inst. 158, 99 (1948).

Washington, September 15, 1948. 